\title{
Families 'At Risk' and the Family Nurse Partnership: The Intrusion of Risk into Social Exclusion Policy
}

\author{
ANNELIESE DODDS \\ Institute for the Study of Public Policy, King's College London \\ email: anneliese.dodds@kcl.ac.uk.
}

\begin{abstract}
This article considers why the family nurse partnership (FNP) has been promoted as a means of tackling social exclusion in the UK. The FNP consists in a programme of visits by nurses to low-income first-time mothers, both while the mothers are pregnant and for the first two years following birth. The FNP is focused on both teaching parenthood and encouraging mothers back into education and/or into employment. Although the FNP marks a considerable discontinuity with previous approaches to family health, it is congruent with an emerging new approach to social exclusion. This new approach maintains that the most important task of social policy is to identify quickly the most 'at-risk' households, individuals and children so that interventions can be targeted more effectively at those 'at risk', either to themselves or to others. The article illustrates this new approach by analysing a succession of reports by the Social Exclusion Unit. It indicates that there is a considerable amount of ambiguity about the relationship between specific risk-factors and being 'at risk of social exclusion'. Nonetheless, this new approach helps to explain why British policy-makers may have chosen to promote the new FNP now.
\end{abstract}

\section{Introduction}

The 'family nurse partnership' (FNP) consists in a programme of visits by nurses to low-income first-time mothers, both while the mothers are pregnant and for the first two years following birth. The FNP is focused on both 'teaching parenthood' and 'encouraging the mother to get an education or a job' (Smith, 2006; see also Family First Health, 2006). Speeches trailing the introduction of the FNP, which proposed early intervention in 'dysfunctional families', were derided in the press as presaging 'foetal asbos' (BBC News, 2006). Yet while the FNP marks a considerable discontinuity with previous approaches to family health, it is congruent with an emerging new approach towards social exclusion. This new approach uses 'risk' as an organising concept, maintaining that the most important task of social policy is to identify quickly 'the most at-risk households, individuals and children so that interventions can be targeted more effectively at those at risk: to themselves or to others' (Her Majesty's Government, 2006a). 
The article indicates how the FNP has been designed to perform these acts of intervention, following the identification of families 'at risk'.

\section{Existing theories of risk in social policy}

A number of works have drawn attention to the growing importance of 'risk' within social policy, which fall into three broad research programmes.

The first research programme has amassed a wealth of historical data to indicate how the state has progressively assumed an important role in insuring against risk - and, specifically, against the risk of loss of income following unemployment, ill health and widowhood (see, for example, Esping-Andersen, 1990; Skocpol, 1992). Some analysts have gone further and maintained that the control or elimination of risk has come to dominate the activities of the state. Hence, Giddens maintains that governments have accepted responsibility not only for the collectivisation of risks from economic and personal problems, but also for dealing with risks arising from globalisation, science and technology (Giddens, 1998); and Moran suggests that risk can be seen as occupying a 'central place' in the modern state (Moran, 2003: 27).

Increasingly, however, analysts are drawing attention to a reverse movement, with those institutions underpinning the collectivisation of risk being challenged by the privatisation of risk (Powell, 2000: 56; Hacker, 2004). This process is seen as occurring across a number of western countries. National populations are, reportedly, increasingly concerned that the state safety net is quickly being unravelled underneath them, but unable to do anything meaningful to stop this (Taylor-Gooby, 2000: 10). Following the decline of state pension provision, the growth of private healthcare programmes and declining levels of real income from state support following unemployment and other misfortunes, individuals are reputedly forced to rely on what Klein and Millar have described as 'DoIt-Yourself social policy. While such individuals are allowed (or required) to exercise autonomous choice over 'DIY' welfare, they also have to accept (to a certain extent) the consequences of such choices (Klein and Millar, 1995: 313-14).

A more recent approach, influenced by Beck's theory of the 'risk society' (Beck, 1992), emphasises how individuals can reflexively approach particular risks, rather than assuming a passive attitude (Ferguson, 2003). Individuals acting in such a way comprise, for Giddens, 'autotelic selves', who do 'not seek to neutralise risk or suppose that "someone else will take care of the problem"; [instead] risk is confronted as the active challenge which generates self-actualisation' (Giddens, 1994: 192).

The phenomenon analysed in this article - the intrusion of the concept of risk into social inclusion policy - has not, however, attracted the same degree of attention. This article maintains that the FNP represents a logical extension of the increasingly pervasive notion that the 'socially excluded' are at risk to themselves 
(and possibly to others). This finding accords with Hazel Kemshall's claim that 'risk, particularly an individualized and responsibilized risk, is replacing need as the core principle of social policy formation and welfare delivery' (Kemshall, 2002: 1).

\section{The family nurse partnership}

The FNP has been promoted by the UK's Social Exclusion Unit (SEU) (an element of the Cabinet Office, under the purview of the Prime Minister, later renamed the 'Social Exclusion Task Force'). It was described in the 2006 'Action Plan on Social Exclusion' as a 'structured program of home visits by trained nurses during pregnancy and the first two years (targeted at disadvantaged families)' (SEU, 2006a: 52). The visits would be focused on 'three major activities': 'promoting improvements in women's (and other family members') behaviour', 'helping women . . . build supportive relationships' and 'linking women and their family members with other services that they need' (ibid.). The family nurse partnership was modelled on the US nurse family partnership, a 30-year old programme operating in a number of states in addition to its original Colorado base. $\mathfrak{L}_{7}$ million was initially invested in 'translating' the US scheme for the UK context, with health visitors and midwives receiving special training to identify and engage 'high-risk families' (Community Care, 2006). The programme has now been piloted in ten areas since March 2007, with a further 20 new test sites identified in March 2008. This process will be supported by $\mathfrak{E}_{30}$ million worth of funding up to 2011.

The US NFP was explicitly presented as a preventative measure. Hence, it was originally operated by the Prevention Research Center for Family and Child Health located within the University of Colorado Health Sciences Center. The SEU described the NFP as an example of an intervention which 'promot[ed] protective factors' (SEU, 2006a: 19). The SEU further suggested that new activity in this area should recognise that 'individuals have a right to take up the opportunities that are available, but also that alongside rights come responsibilities' (SEU, 2006a: 20).

An important element stressed by those promoting the NFP as an option for Britain was its effectiveness as proved through 'clinical' trials in a variety of social settings (Olds et al., 2002, 2007). A number of commentators invoked a US study of over 100 families involved in the scheme between 1977 and 1994, which 'found that child abuse and neglect were halved when children reached 15 ... [a]rrests were reduced by nearly two-thirds and there was a 90 per cent reduction in poor behaviour' (Community Care, 2006). This study was also mentioned in the SEU's Action Plan, which maintained that 'three separate largescale, randomised controlled trials' indicated that the NFP had led to everything from fewer 'kidney infections' to '[f] ewer lifetime sex partners' (SEU, 2006a: 
52). ${ }^{1}$ The founder of the scheme maintained that success in these trials gave the NFP a particular status which distinguished it from alternative attempts to improve child welfare. In particular, he was critical of proposals to introduce 'European'-style systems of child benefits in the US, maintaining that comparative evidence was not sufficiently rigorous to justify public expenditure. Indeed, he suggested that only policies which had passed 'randomised trials' could be used to support young families, since only they could be 'effective and thus moral' (Olds, 1996: 3).

The FNP/NFP marks a considerable change from existing models of service provision in Britain. Aside from the risk-based arguments which are analysed below, one of the arguments used in favour of the scheme (interestingly, mainly by British rather than US proponents) is that part of the reason for using health professionals rather than social workers or other state employees was the fact that FNP nurses would be seen as trustworthy by potential clients (see comments of Kate Billingham, project director responsible for evaluating a programme of pilot projects, quoted in Valios, 2007). As Hilary Armstrong, the Minister for Social Exclusion, suggested, the scheme was promoted because, for those people who 'have had a bad experience of the state', health-led models would be more trusted and therefore accessible (Armstrong, 2006). The fact that the scheme was voluntary (that is, that mothers had to opt in rather than opt out of it), and did not offer financial incentives to induce compliance, also distinguished the NFP from compulsory US schemes such as 'workfare' or 'bridefare'. Some concerns have been raised that the substantial impact of the scheme in the US may have been at least partly related to the lack of universal services accessible to low-income mothers and children in that country, a factor which is less relevant in the UK case (Ward, 2007), although this has not yet been substantiated (an evaluation of the ten pilot sites is currently being carried out by the University of London).

One of the main claims made by proponents of the NFP has been its links to improved levels of child health, especially through educating mothers about healthy living. However, the lifestyle changes required in order to live more healthily may either be impossible to achieve for some people due to structural problems, or they may be very expensive (Child Poverty Action Group, 2001). As Davison et al. note, '[t]he almost exclusive concentration by health educators and promoters on behaviours said to be open to individual choice, should be re-examined' (1992: 109). Focusing exclusively on individuals' responsibility for health improvement has been described as removing responsibility from the state for individuals' well-being, since poor health is still significantly, and steeply, correlated with individuals' socio-economic position, which could (in theory) be altered by income redistribution (Freeman, 1992: 44-5). A purely individualised approach to health improvement also ignores the independent 
effects of inequality in health, which applies regardless of individuals' absolute income levels (beyond subsistence levels) (Wilkinson, 2005).

\section{The new use of 'risk' in social exclusion policy}

Given this context, it is legitimate to ask why the FNP has been given such prominence as a new policy programme to help tackle social exclusion, not least since the NFP has been operating in the US for a number of years. The rest of this article suggests that this can be at least partly explained by the way in which the concept of 'risk' has intruded into policy on social exclusion.

For the SEU, social exclusion is 'a shorthand term for what can happen when people or areas suffer from a combination of linked problems such as unemployment, poor skills, low incomes, poor housing, high crime, bad health and family breakdown' (Cabinet Office, 2008). The concept of 'social exclusion' was institutionalised in Britain in 1998 with the creation of the Social Exclusion Unit within the Cabinet Office. Some have criticised the concept as 'intrinsically problematic', leading to 'power and privilege slipping out of focus if not out of sight', with 'structural inequalities' remaining 'largely uninterrogated' (Levitas, 1998: 7). Others, however, have described the pursuit of social inclusion as a legitimate policy goal (Layard, 1997), one which recognises that not all inequalities are economic (Witcher, 2003). A considerable volume of work has been generated concerning the appropriateness or otherwise of the concept. ${ }^{2}$

Regardless of the merits or otherwise of using 'social exclusion' as an analytical category, it is clear that its use has changed substantially over recent years. In particular, individuals are increasingly being described as 'at risk' of social exclusion, or even simply 'at risk', rather than as (actually) 'socially excluded'. Hence, the SEU maintained in its 2001 report 'Preventing Social Exclusion' that '[s]ocial exclusion is something that can happen to anyone. But some people are significantly more at risk than others' (SEU, 2001d: 13). Henceforth, government action has been focused on 'reducing the numbers who go through experiences that put them at risk or targeting action to compensate for the impact of these experiences' (ibid.). In late 2006, the Social Exclusion Unit was renamed the Social Exclusion Task Force, and its new Head defined her role as pushing forward 'earlier identification and support for those at risk of deep-rooted exclusion' (Her Majesty's Government, 2006b).

The growing importance of this new, risk-based approach to social exclusion can be seen by measuring the use of the term 'risk' in reports produced by the SEU before its metamorphosis into the Social Exclusion Task Force in 2006. Table 1 indicates the relative use of different conceptualisations of risk in the 91 publications produced by the SEU which are publicly available through the SEU's archive. ${ }^{3}$ The reported measurements combined a very basic frequency count 
TABLE 1. The proportionate use of particular conceptualisations of risk in Social Exclusion Unit publications, from 1998 to 2006 (percentage rounded up from 0.05 to nearest decimal)

\begin{tabular}{|c|c|c|c|c|c|c|c|c|c|c|}
\hline Risk. . . & 1998 & 1999 & 2000 & 2001 & 2002 & 2003 & 2004 & 2005 & 2006 & $\begin{array}{c}\text { Date } \\
\text { unclear }\end{array}$ \\
\hline $\begin{array}{r}\ldots \text { of social } \\
\text { exclusion }\end{array}$ & & $4 \cdot 9$ & 5.6 & 19.1 & 26.7 & $33 \cdot 3$ & 32.1 & 15.2 & $7 \cdot 3$ & 26.3 \\
\hline $\begin{array}{l}\text { At unspecified } \\
\text { risk ("at risk") }\end{array}$ & 20 & 8.2 & 31.3 & 17.6 & $43 \cdot 3$ & 25 & $7 \cdot 7$ & 9.1 & 53.7 & 10.5 \\
\hline ... of exclusion & & 2.2 & 2.1 & 10.3 & & 4.2 & 1.0 & 3.0 & 6.1 & 21.1 \\
\hline $\begin{array}{l}\text { Non-specific } \\
\text { risks total }\end{array}$ & 20 & $15 \cdot 3$ & 39 & 47 & 70 & 62.5 & 40.8 & $27 \cdot 3$ & 67.1 & 57.9 \\
\hline $\begin{array}{l}\text {. oof } \\
\text { unemployment }\end{array}$ & & 2.7 & 8.3 & 1.5 & 1.7 & & 5.8 & 3.0 & 1.2 & \\
\hline $\begin{array}{c}\ldots \text { of exclusion } \\
\text { from school }\end{array}$ & & 7.1 & 1.4 & 7.4 & 1.7 & 4.2 & 1.0 & 1.5 & & 15.8 \\
\hline $\begin{array}{c}\ldots \text { of teenage } \\
\text { pregnancy }\end{array}$ & & 8.2 & .7 & $4 \cdot 4$ & $3 \cdot 3$ & 4.2 & .6 & & & \\
\hline $\begin{array}{l}\ldots \text { of experiencing } \\
\text { crime/ASB }\end{array}$ & & $3 \cdot 3$ & 7.6 & 2.9 & & 4.2 & 4.2 & 7.6 & $3 \cdot 7$ & \\
\hline $\begin{array}{l}\ldots \text { of committing } \\
\text { crime/ASB }\end{array}$ & & 1.1 & 2.1 & 1.5 & 1.7 & 8.3 & 2.2 & 12.1 & 1.2 & 21.1 \\
\hline $\begin{array}{l}\ldots \text { of } \\
\text { homelessness }\end{array}$ & & .5 & 2.1 & $7 \cdot 4$ & 5.0 & & 3.8 & 7.6 & 2.4 & \\
\hline $\begin{array}{l}\text {. o of early } \\
\text { mortality/illness }\end{array}$ & 20 & 1.1 & .7 & & & & 6.1 & 1.5 & 1.2 & \\
\hline $\begin{array}{l}\ldots \text { of specific } \\
\text { illness }\end{array}$ & & $3 \cdot 3$ & & 2.9 & 1.7 & 4.2 & 2.6 & & 1.2 & \\
\hline ...of low pay & & 1.1 & .7 & & & & 1.3 & & & \\
\hline ...of poverty & & 1.6 & & 2.9 & & & 4.8 & & & \\
\hline . . of disadvantage & & .5 & .7 & 1.5 & & & 1.3 & & & \\
\hline ... of financial loss & & 6.0 & & 2.9 & & & 2.2 & 1.5 & 1.2 & \\
\hline $\begin{array}{l}\text { Specific risks } \\
\text { total }\end{array}$ & 20 & 36.5 & $24 \cdot 3$ & 38.2 & 15.1 & 25.1 & 35.9 & 34.8 & 12.1 & 36.9 \\
\hline "Risk factors" & & 7.1 & 20.1 & $4 \cdot 4$ & $3 \cdot 3$ & 8.3 & 18.9 & 15.2 & 9.8 & \\
\hline "Risk assessment" & & 6.6 & 1.4 & 5.9 & $3 \cdot 3$ & & 1.0 & 1.5 & $3 \cdot 7$ & \\
\hline
\end{tabular}

of the propositional unit 'risk' within all 91 publications with an examination of the context of the term 'risk' with the surrounding text. It thus combined different 'traditions' of documentary analysis (Jupp and Norris, 1993), using basic quantitative analysis within the context of a qualitative appreciation of the role of 'risk' within the reports.

The different figures represent the percentage of times particular conceptualisations of risk occurred within any particular year (rounded up from 0.05 per cent). The figures should be taken as only a rough indication of the extent of usage of different terms, since the SEU produced quite wildly varying volumes of publications each year, and since particular years' totals are 'skewed' by reports dealing with particular issues (the clearest example 
of this being in 1998 when only one report was produced, concerning rough sleeping, which naturally led to a focus on those risks related to homelessness). Only those conceptualisations of risks identified in the first column counted towards the 'total' number of conceptualisations. Conceptualisations which did not substantially recur throughout the sample were excluded.

The conventions used in drawing up Table 1 are explained in Appendix A. This indicates which terms were placed under different categories. For example, the reported frequency of mentions of 'risks of poverty' is taken as including the risks of: being poor, living in poverty, children falling into poverty, persistent and/or severe poverty for children and child poverty.

Of course, it can be questioned whether the use of particular language need have any concrete impact. Different conceptualisations of 'risk' may merely substitute for alternative terms such as 'liability' or 'likelihood', which were perhaps used more frequently in the past. ${ }^{4}$ However, as Levitas notes, 'interrelated concepts act together as a matrix through which we understand the social world. As this matrix structures our understanding, so it in turn governs the paths of action which appear to be open to us' (Levitas, 1998: 3). Indeed, many of the SEU's publications themselves contained the first descriptions of new policies, such as the FNP proposal. It is therefore useful to consider how the SEU's discourse concerning social exclusion has come to incorporate the notion of 'risk'.

\section{'At risk'- of what?}

As shown by Table 1, a whole variety of specific risks to individuals were examined in SEU publications, and it is difficult to draw any conclusions from the frequency of these. ${ }^{5}$ Some general conclusions can, however, be made concerning the relative weight of references to specific risks when compared to general or non-specific risks. The table indicates that mention of specific risks by the SEU was almost always outweighed by references to unspecified risks (the general 'risk of social exclusion', the 'risk of exclusion', or simply being 'at risk'). There was a particularly significant number of references to those 'at risk' (without explaining what they were at risk of) in the reports produced by the SEU in 2006. The table also indicates that SEU publications frequently referred to those subject to such risks as 'high-risk' individuals or groups, or people participating in 'high-risk' activities or living in 'high-risk' areas.

Parton et al. (1997) have examined in depth how the original use of the term 'at risk' came to be generalised within child protection services, substituting for previous concepts such as 'needy children'. In distinction to this use, however, the new use of the term 'at risk' does not refer to any specific risk. ${ }^{6}$ Indeed, a number of SEU publications continue to use this latter child protection-related conceptualisation, either placing 'at risk' in quotation marks to refer to the old 
meaning (SEU, 2002C, 2004g), or explicitly linking being 'at risk' with 'on the child protection register' (SEU, 2001b, 2005e). The ambiguity implied by these multiple meanings is interesting given the inclusion of child protection within the goals of the FNP.

\section{Who is at risk, and why?}

Given that the FNP targets those identified as 'at (non-specific) risk', it is perhaps pertinent to consider how any process of identification would work. SEU publications are not particularly detailed on this matter. Hence, on a number of occasions, the term 'experiencing or at risk of social exclusion' was invoked, without ever differentiating between the categories of experience and susceptibility (SEU, 2000a, 2002a, 2004g, 2006a: 54), and at one point being 'socially excluded' was apparently treated as synonymous with being 'at risk of social exclusion' (SEU, 2002a).7 A 2004 report did, however, attempt to quantify the numbers of those 'at risk of social exclusion' (if not of those non-specifically 'at risk') as referring to all those children living in low-income households, as compared with smaller numbers of people subject to 'extreme forms of multiple deprivation, affecting only $1 \%$ or so of the relevant population' and those subject to "'significant problems", which may affect some 1 in 10 of the age group' from birth to 13 years (SEU, 2004g: 17).

As shown in Table 1, a number of SEU publications referred to 'risk factors' which might predispose individuals to become socially excluded. The table also indicates that the term 'risk assessment' was frequently mentioned, with risk assessment often being promoted as a technology for professionals to use when dealing with individuals 'at risk' (see, for example, SEU, 1999b).

The 'risk factors' identified in SEU publications were described as 'cumulative', such that 'if the "chain" can be broken, most children can recover' (SEU, 2004g: 21). Some risk factors were described as 'predictive' (albeit only ' [a]t a population level'), and 'symptoms of an individual being at risk of social exclusion [could be identified by services] at an early stage' (SEU, 2005a: 134). Despite this, some publications were keen to note that the '[c] oincidence of problems in specific at-risk groups' should not be 'taken to infer causality in either direction' (SEU, 2000a: 101). In one report, the 'causes and consequences of social exclusion' were treated as identical (consisting in 'poverty and low income; unemployment; poor educational attainment; poor mental or physical health; family breakdown and poor parenting; poor housing and homelessness; discrimination; crime; and living in a disadvantaged area' (SEU, 2004d: 3)). Furthermore, the presence of individual risk factors was sometimes seen as insufficient for the onset of social exclusion since, for example '[o]ne-off or low-level anti-social behaviour, such as litter dropping, may be perpetrated by people who have none of the "risk factors" identified' (SEU, 200od: 25). 
Despite this recurrent ambiguity, a number of the SEU publications referred to the goal of both reducing 'the risk that people become socially excluded', or reducing 'the risks associated with social exclusion' (SEU, 2005a, 2004g), and 'strengthening the protective factors' that enable people 'to overcome the risks and obstacles they face' (SEU, 2000a: 28). A succession of reports described different sets of 'risk' and 'protective' or 'preventive factors' (SEU, 2000a, 2001c, 2004g, 2005c). The development of 'protective' or 'preventive factors' was described as 'resilience' or 'resiliency' (SEU, 2004g, 2005a). One report suggested that such 'resiliency' could be promoted by 'making opportunities and encouraging children and their parents to take advantage of them' (SEU, 2004g: 114).

\section{The FNP and the role of risk in social exclusion}

The above analysis suggests that we are witnessing a change in social policy, to the extent that this is driven by the SEU, with an increasing focus on those individuals who are deemed 'at risk' and on building up those individuals' 'resilience' to risks. The FNP can be seen as an appropriate policy in this context. The FNP does not offer mothers any additional funds or resources, and it does not create for them any new opportunities. Instead, it aims to educate mothers how to bring up their children more successfully, and how to improve their own job prospects, in the process making them more resilient.

The FNP thus mainly aims at building up individuals' 'resilience to risk'. Some elements of the FNP may enable family members to access available resources better, through facilitating linkages with other agencies and services. Beyond this, however, the FNP does not itself attempt to change the material context in which individuals live, nor to itself reduce the risks they face.

This approach perhaps resonates with discussions of agency within SEU reports produced before the FNP was placed on the agenda. For example, one SEU report from 2004 maintained that, with respect to 'the poorest and some ethnic minority groups', it is 'not ... enough to reduce the risk, or present the opportunities', since these individuals 'also need a helping hand to ... discover that exercising "agency" can make a difference' (SEU, 2004g: 121). Indeed, according to the SEU, those most 'at risk' may be suffering from 'learned helplessness', whereby they need a 'helping hand to develop the confidence, skills and strategies to escape from social exclusion' (ibid.).

This approach assumes that those 'at risk' are, on at least some occasions, unable to act in their own interests. In assuming that those 'at risk' are, in this respect, irrational, it contrasts with Charles Murray's approach to poverty, with Murray maintaining that long-term benefits recipients were acting rationally in response to government policy (Prideaux, 2005: 136). ${ }^{8}$ The SEU's approach does acknowledge that 'structure' has an important role to play, with an 'early life of disadvantage' possibly resulting in 'a deeply-held belief that nothing can 
change' (SEU, 2004g: 22). It can, therefore, be distinguished from what Scott and Williams have described as the 'punitive, victim-blaming turn in social policy, where behaviour is divorced from its social context and risk-taking is represented as willful deviance' (Scott and Williams, 1992: 4), and also from cultural explanations for poverty which maintain that the ethos of certain groups provides a breeding ground for 'social pathologies' (Moynihan, 1968).

However, the SEU's approach accords relatively minor significance to current, as opposed to past, structural and material factors. In so doing, it underplays the role of social, economic, racial and gender inequality in explaining poverty and allegedly undesirable behaviour such as teenage pregnancy (O'Connor, 2001: 255; Robinson and Gregson, 1992). It may also underplay the extent to which those 'at risk' are already aware of routes out of poverty, but are unable to follow these routes for a variety of structural reasons.

\section{Conclusion}

This article has considered why the FNP has been promoted as a new policy to tackle social exclusion in the UK. It has detailed how proponents of the FNP link its operation to reduced 'risks' of everything from kidney problems to promiscuity, and explicitly propose that the new scheme should be focused on those 'at risk'. The FNP thus fits with the SEU's new focus on enabling individuals to become 'resilient' to the risks that they face, not necessarily through providing extra resources or tackling structural barriers, but through the exhortation and encouragement of professionals.

This approach may, however, have limited impact in a context of constrained resources. Merely teaching young mothers how to keep their children safe and healthy will have few benefits if those mothers are unable to afford the time to supervise their children or to travel out of the community, if necessary, to shop for healthy food; or the money to pay for safety equipment and nutritious groceries. A similar point can be made with regard to transitions into paid work. Numerous studies have indicated that the long-term unemployed are as willing to undertake retraining and to enter paid work as the rest of the population: indeed, they may even be more motivated than the employed population (Taylor-Gooby and Dean, 1992, 76: 91-2; Gallie et al., 1994; Newman, 2000: 51; Bradshaw and Holmes, 1989: 138).

Instead of acknowledging the need for increased support for those living on low incomes, the US welfare system has increasingly become entwined with moral aspirations to manufacture 'better' clients and citizens (Soss, 2005). The SEU's focus on individually based, therapeutic approaches, exemplified by the FNP, suggests that British welfare policy may be leaning in the same direction. 


\section{Appendix A: Conventions used in drawing up Table 1}

'Risk of experiencing crime' includes: risk of repeat victimisation, crime due to living above commercial premises (SEU, 1999h); risk from criminals (SEU, 2000c); risk of theft, burglary (SEU, 200oe); risk of repeat victimisation (SEU, 2001c); risk of being a victim of racist crime (SEU, 2004e); risk of repeat victimisation (2004i); and risk of sexual assault (SEU, 2005d).

'Risk of specific illness' includes risks of: reproductive problems, genital herpes, STIs, obstetric risks (SEU, 1999a); cardiovascular disease and diabetes, mental health problems (SEU, 2004b); stroke and stomach cancer; hepatitis and HIV (SEU, 2004h); suffering specific conditions or diseases, diabetes (SEU, 2004i); and heart disease (SEU, 2006b).

'Risk of poverty' includes: risk of being poor, living in poverty (SEU, 1999a); risks of children falling into poverty, risk of persistent and/or severe poverty for children (SEU, 2004b); and risk of poverty/living in poverty, risk of child poverty (SEU, 2004h)

'Risk of financial loss (to individuals)' includes: risk of making transition to work off benefits, risk that the payment of certain in-work benefits such as Housing Benefit and Council Tax Benefit would be delayed, risk that . . . it would be time-consuming to re-establish benefits ... (and) their entitlement to disability benefit (would be called into question) (SEU, 1999c); risk of indebtedness, risk of bankruptcy, risk of losing existing benefit entitlement (SEU, 1999e); risk of an unauthorised overdraft (SEU, 1999i); risk of losing benefit, risk of an unauthorised overdraft (SEU, 2001c); risk of default, risk of debt, risk of debt problems (SEU, 2004a); risks involved in the transition to work/giving up benefits for an insecure job, financially risky (SEU, 2004e); risk of mortgage arrears (SEU, 2004f); and risk losing a proportion of their Income Support (SEU, 2005a).

'Risk of financial loss (to companies)' includes: risk of recruiting from them, people who represent the minimum risk, risks which employers perceive when recruiting jobless people (SEU, 1999c); risk in employing someone, risks if those staff leave or become ill (SEU, 1999d); risk of business failure, risks of increasing their involvement, financial risks, financially risky, risk to the lender/risk of lending/riskiness of the lending, default risk, credit risk and so on (SEU, 1999e); risk of default, credit risk, financial risk (SEU, 1999i); and business risks (SEU, 2001c).

'Risk to service delivery' includes: risk that problems are displaced rather than solved (SEU, 1998); risks of local strategies (SEU, 1999a); risks to the SEU itself (SEU, 1999b); risk of increasing the gap between those communities who are information poor and those areas which are information rich; risk of inaccurate information; risk of people withholding information needed to recalculate benefit entitlements, risks associated with a more generous regime of earnings disregards, risk of increasing the gap between those communities 
who are information poor and those areas which are information rich (SEU, 1999c); risk of losing touch with developments on estates, risks that the costs resulting from doing nothing would actually be much greater (SEU, 1999f); risk of isolation of community development workers (SEU, 1999h); risk of rules intended to protect the generality of consumers having the unintended effect of inhibiting access by low-income groups (SEU, 1999f); risk that new initiatives could actually add so much confusion that their underlying goals are seriously jeopardised (SEU, 2000a); risks to the delivery of the strategy (SEU, 2001a); risk that any organisation with 'children's rights' in the title will be seen as a panacea to each child's concerns, risk that the majority of services in social care - adult care services - get seen as the norm (SEU, 2002b); risk that someone counted as deprived according to a particular set of indicators may in fact have a reasonable standard of living (SEU, 2004f); risk of not delivering the 2010 decent homes target/achievement of the overall target (for 1999-2004) is now at risk, risk is an apparent scatter of initiatives (SEU, 2004g); risks of incomplete and/or unreliable results that follow from making the provision of information on ethnic origin a voluntary act (SEU, 2004i); risk of these young adults falling through a gap between child and adult services (SEU, 2005a); risk violating the DPA (SEU, $2005 \mathrm{~b}$ ); policy interventions aimed at young people risk failing (SEU, 2005c); and risk of appearing 'nannying', risk that services that make very extensive use of former service users unintentionally give service users a message that their best career option is to become a personal adviser or youth worker themselves (SEU, 2005d).

'Risk described as positive' includes: ability to navigate 'risk' or to be enterprising (SEU, 1999d); funders [can be] risk-averse, risks with public money (SEU, 1999g); encourages innovators and risk-takers (SEU, 1999h); risk taking [as a core skill], social entrepreneurs [as] risk-takers, appraising risks, risk aversion/risk-averse culture, a charity or some other not-for-profit takes a risk too many, we see it as a scandal (SEU, 200ob); new leaders across the system, generating a wide commitment to act, learn and take risks, risk aversion, the community and voluntary sector can: [t]ake risks (SEU, 2oood); innovation and risk-taking are encouraged (SEU, 2001c); willing to take risks to help those finding it hardest to get work (SEU, 2003); often well-placed to take risks (SEU, 2004c); guidance may take a ... risk-averse line, risk-taking, risks that they are responsible for (SEU, 2005a); private sector will take the risk, risk-averse culture/averse to taking risks (SEU, 2005b); risk-averse rules (SEU, undated).

\section{Acknowledgements}

The author would like to thank participants at the Social Contexts and Responses to Risk conference, 'Risk and Rationalities', 29-31 March 2007, and three anonymous reviewers for their helpful and perceptive comments on an earlier version of this paper. 


\section{Notes}

1 The SEU did, however, state in a footnote that these outcomes were reported for only one of the trials (2006a, footnote 56), and others have noted that 'results at replication sites are somewhat weaker than at model sites' (O'Brien, 2005: 241).

2 For an interesting survey and comparison with 'lay' views, see Richardson and Le Grand (2002).

3 It thus excludes the eighth edition of the SEU's publication 'Inclusion', since this failed to load from the archive website; but includes all other reports, letters and factsheets classified by the SEU as 'publications'.

4 This appears to have been the case where the SEU has used the concept of 'risk' as if it were synonymous with 'likelihood' (see SEU, 2006b: 20).

5 Additional uses of the term 'risk' which are less relevant for present purposes included positive uses of the term (such as the presentation of risk as a resource to be taken advantage of in the economy, linked with entrepreneurialism and innovation, and also as a resource to be used by welfare professionals and voluntary groups), and discussion of risks to business and to government (in particular, risks posed to the effective enactment of government policies).

6 It appears that the term has also been used in this non-specific manner in the US, albeit only relatively recently; see for example its use by Armacost et al. (2001: v).

7 'Not everyone who experiences social exclusion will necessarily have a transport problem, and not everyone with transport problems is at risk of social exclusion' (SEU, 2002a: 1).

8 Although it should be noted that Murray moderated his line on this subject later, stating that he was 'using the concept of blame as a useful fiction', because 'even if it is true that a poor young person is not responsible for the condition in which he finds himself, the worst thing one can do is try and persuade him of that' (Murray, 1996: 84).

\section{References}

Armacost, M., Laracy, M. and Phillips, J. (2001), 'Foreword', in R. M. Blank and R. Haskins (eds.), The New World of Welfare, Washington, DC: Brookings Institution Press.

Armstrong, H. (2006), 'Interview for Epolitix', www.epolitix.com/EN/Interviews/200609/ 131229c8-3dae-4e53-9bfb-f35795c82787.htm, accessed 14 January 2007.

BBC News (2006), “Problem families” scheme set out: Mr Blair wants to prevent teenage criminality', BBC News, 5 September.

Beck, U. (1992), Risk Society: Towards a New Modernity, London: Sage.

Bradshaw, J. and Holmes, H. (1989), Living on the Edge: A Study of the Living Standards of Families on Benefit in Tyne and Wear, Tyneside Child Poverty Action Group, London: Child Poverty Action Group.

Cabinet Office (2008), 'Context for social exclusion work', Social Exclusion Task Force web site, London, accessed January 2009.

Child Poverty Action Group (2001), Poverty Bites: Food, Health and Poor Families, London: Child Poverty Action Group.

Community Care (2006), 'Time for Armstrong to deliver', 14 September, www. communitycare.co.uk/Articles/2006/09/14/55697/Time+for+Armstrong+to+deliver. html, accessed 14 January 2007.

Davison, C., Frankel, S. and Smith, G. D. (1992), “"To hell with tomorrow”: coronary heart disease risk and the ethnography of fatalism', in S. Scott, G. Williams, S. Platt and H. Thomas (eds.), Private Risks and Public Dangers, Aldershot: Avebury.

Esping-Andersen, G. (1990), The Three Worlds of Welfare Capitalism, Cambridge: Polity Press. Family First Health (2006), 'Nurse-family partnership', www.familyfirsthealth.org/nfp2.html, accessed 14 January 2007.

\section{CAMBRIDGE}


Ferguson, H. (2003), 'Welfare, social exclusion and reflexivity: the case of child and woman protection', Journal of Social Policy, 32: 2, 199-216.

Freeman, R. (1992), 'The idea of prevention: a critical view', in S. Scott, G. Williams, S. Platt and H. Thomas (eds.), Private Risks and Public Dangers, Aldershot: Avebury.

Gallie, D., Marsh, C. and Vogler, C. (1994), Social Change and the Experience of Unemployment, Oxford: Oxford University Press.

Giddens, A. (1994), Beyond Left and Right: The Future of Radical Politics, Stanford, California: Stanford University Press.

Giddens, A. (1998), The Third Way: The Renewal of Social Democracy, Oxford: Polity Press.

Hacker, J. (2004), 'Privatizing risk without privatizing the welfare state: the hidden politics of social policy retrenchment in the United States', American Political Science Review, 98: 2, 243-60.

Her Majesty's Government (2006a), 'Tackling deep-seated social exclusion: Hilary Armstrong announces next steps and new arrangements in government', Cabinet press release, Social Exclusion Task Force, 13 June, CAB/035/06.

Her Majesty's Government (2006b), 'Cabinet Office announces new Head for Social', press release, Exclusion Task Force, 22 November, CAB/o68/o6.

Jupp, V. and Norris, N. (1993), 'Traditions in documentary analysis', in M. Hammersley (ed.), Social Research: Philosophy, Politics and Practice, London: Sage.

Kemshall, H. (2002), Risk, Social Policy and Welfare, Buckingham: Open University Press.

Klein, R. and Millar, J. (1995), 'Do-it-yourself social policy: searching for a new paradigm?', Social Policy and Administration, 29: 4, 303-16.

Layard, R. (1997), What Labour Can Do, London: Warner Books.

Levitas, R. (1998), The Inclusive Society? Social Exclusion and New Labour, London: Palgrave Macmillan.

Moran, M. (2003), The British Regulatory State: High Modernism and Hyper-Innovation, Oxford: Oxford University Press.

Moynihan, D. P. (1968), The Negro Family - The Case for National Action, Office of Planning and Research, Washington, DC: US Department of Labor.

Murray, C. (1996), Charles Murray and the Underclass: The Developing Debate, London: IEA Health and Welfare Unit in association with The Sunday Times.

Newman, K. S. (2000), No Shame in my Game: The Working Poor in the Inner City, New York: Vintage Books.

O'Brien, R. (2005), 'Translating a research intervention into community practice: the Nurse Family Partnership', Journal of Primary Prevention, 26: 3, 241-57.

O'Connor, A. (2001), Poverty Knowledge: Social Science, Social Policy and the Poor in TwentiethCentury US History, Princeton and Oxford: Princeton University Press.

Olds, D. (1996), 'Review of "Starting Right": how America neglects its youngest children and what we can do about it', Social Service Review, 70: 4.

Olds, D. L., Robinson, J., O’Brien, R., Luckey, D. W., Pettitt, L. M., Henderson, C. R., Ng, R. K., Sheff, K. L., Korfmacher, J., Hiatt, S. and Talmi, A. (2002), 'Home visiting by paraprofessionals and by nurses: a randomized, controlled trial', Pediatrics, 110: 486-96.

Olds, D. L., Kitzman, H., Hanks, C., Cole, R., Anson, E., Sidora-Arcoleo, K., Luckey, D. W., Henderson, C. R., Holmberg, J., Tutt, R. A., Stevenson, A. J. and Bondy, J. (2007), 'Effects of nurse home visiting on maternal and child functioning: age-9', Pediatrics, 120: 832-45.

Parton, N., Thorpe, D. and Wattam, C. (1997), Child Protection: Risk and the Moral Order, Basingstoke: Macmillan.

Powell, M. (2000), 'New labour and the third way in the British welfare state: a new and distinctive approach?', Criticial Social Policy, 20: 1, 39-60.

Prideaux, S. (2005), Not So New Labour: A Sociological Critique of New Labour's Policy and Practice, Bristol: Policy Press.

Richardson, L. and Le Grand, J. (2002), 'Outsider and insider expertise: the response of residents of deprived neighbourhoods to an academic definition of social exclusion', CASE Paper, Centre for the Analysis of Social Exclusion, London: London School of Economics. 
Robinson, F. and Gregson, N. (1992), 'The underclass - a class apart?', Critical Social Policy, 34: $38-51$.

Scott, S. and Williams, G. (1992), 'Introduction', in S. Scott, G. Williams, S. Platt and H. Thomas (eds.), Private Risks and Public Dangers, Aldershot: Avebury.

Skocpol, T. (1992), Protecting Soldiers and Mothers: The Political Origins of Social Policy in the United States, Cambridge, MA: Belknap Press of Harvard University Press.

Smith, C. (2006), 'Mom school: fixing children's services is only half the battle', New York Metro, 20 February.

SEU (Social Exclusion Unit) (1998), Rough Sleeping - Report by the Social Exclusion Unit, London: Social Exclusion Unit.

SEU (1999a), Teenage Pregnancy, London: Social Exclusion Unit.

SEU (1999b), Bridging the Gap - New Opportunities for 16-18 Year Olds not in Education, Employment or Training London: Social Exclusion Unit.

SEU (1999C), A Review of the Social Exclusion Unit, London: Social Exclusion Unit.

SEU (1999d), PAT o1 - Jobs for all Policy Action Team, report 1, London: Social Exclusion Unit.

SEU (1999e), PAT o2 - Skills, London: Social Exclusion Unit.

SEU (1999f), PAT o3 - Enterprise and Social Exclusion, London: Social Exclusion Unit.

SEU (1999g), PAT o7 - Unpopular Housing, London: Social Exclusion Unit.

SEU (1999h), PAT 11 - Schools Plus: Building Learning Communities, London: Social Exclusion Unit.

SEU (1999i), PAT 13 - Improving Shopping Access for People Living in Deprived Neighbourhoods, London: Social Exclusion Unit.

SEU (2000a), PAT 12 - Young People, London: Social Exclusion Unit.

SEU (200ob), PAT 16 - Learning Lessons, London: Social Exclusion Unit.

SEU (2000c), PAT o8 - Anti-social Behaviour, London: Social Exclusion Unit.

SEU (20ood), PAT 18 - Better Information, London: Social Exclusion Unit.

SEU (200oe), PAT Report Summaries: A Compendium, London: Social Exclusion Unit.

SEU (2001a), A New Commitment to Neighbourhood Renewal National Strategy Action Plan, London: Social Exclusion Unit.

SEU (2001b), Consultation on Young Runaways, London: Social Exclusion Unit.

SEU (2001c), PAT Audit - National Strategy for Neighbourhood Renewal, London: Social Exclusion Unit.

SEU (2001d), Preventing Social Exclusion, London: Social Exclusion Unit.

SEU (2002a), Making the Connections: Transport and Social Exclusion, interim findings, London: Social Exclusion Unit.

SEU (2002b), Inclusion 2, London: Social Exclusion Unit.

SEU (2002c), Young Runaways Report, London: Social Exclusion Unit.

SEU (2003), Inclusion 6, London: Social Exclusion Unit.

SEU (2004a), Action on Debt, factpack produced by the Social Exclusion Unit short studies team, London: Social Exclusion Unit.

SEU (2004b), Mental Health and Social Exclusion, final report, London: Social Exclusion Unit.

SEU (2004c), Inclusion 10, London: Social Exclusion Unit.

SEU (2004d), Breaking the Cycle - Taking Stock of Progress and Priorities for the Future, summary report, London: Social Exclusion Unit.

SEU (2004e), Jobs and Enterprise in Deprived Areas, London: Social Exclusion Unit.

SEU (2004f), Low Income and Multiple Disadvantage 1991-2001: Analysis of the British Household Panel Survey, main report, London: Social Exclusion Unit.

SEU (2004g), The Impact of Government Policy on Social Exclusion among Children Aged o-13 and Their Families: A Review of the Literature for the Social Exclusion Unit in the Breaking the Cycle Series, main report, London: Social Exclusion Unit.

SEU (2004h), Project Scoping Note: Better Service Delivery for Disadvantaged People who Move Frequently, final version, London: Social Exclusion Unit.

SEU (2004i), Jobs and Enterprise in Deprived Areas, summary report, London: Social Exclusion Unit.

\section{CAMBridge JDURNALS}


SEU (2005a), Improving Services, Improving Lives: Evidence and Key Themes, interim report, London: Social Exclusion Unit.

SEU (2005b), Inclusion through Innovation - Summary of Questionnaire Responses, London: Social Exclusion Unit.

SEU (2005c), Transitions, interim report on young adults, London: Social Exclusion Unit.

SEU (2005d), Transitions: Young Adults with Complex Needs, London: Social Exclusion Unit.

SEU (2005e), Better Government for Older People, summary of report, London: Social Exclusion Unit.

SEU (2006a), Reaching Out: An Action Plan on Social Exclusion, London: Social Exclusion Unit.

SEU (2006b), A Sure Start to Later Life: Ending Inequalities for Older People Summary, London: Social Exclusion Unit.

SEU (Undated), PAT 10 - Arts \& Sport, London: Social Exclusion Unit.

Soss, J. (2005), 'Making clients and citizens: welfare policy as a source of status, belief and action', in A. Schneider and H. Ingram (eds.), Deserving and Entitled: Social Constructions and Public Policy, Albany, New York: State University of New York Press.

Taylor-Gooby P. (ed.) (200o), Risk, Trust and Welfare, London: Macmillan.

Taylor-Gooby, P. and Dean, H. (1992), Dependency Culture: The Explosion of a Myth, London: Harvester Wheatsheaf.

Valios, N. (2007), 'The earlier the better', Community Care, 26 July, reprinted as 'US project to improve child health and welfare rolled out in UK', http://www.communitycare.co. uk/Articles/2007/07/25/105242/us-project-to-improve-child-health-and-welfare-rolledout-in-uk.html, accessed January 2009.

Ward, L. (2007), 'Q\&A: Nurse Family Partnership programme', Guardian Unlimited, 16 May.

Wilkinson, R. (2005), The Impact of Inequality: How to Make Sick Societies Healthier, London: Routledge.

Witcher, S. (2003), Reviewing the Terms of Inclusion: Transactional Processes, Currencies and Context, CASE Paper, Centre for the Analysis of Social Exclusion, London: London School of Economics.

\section{CAMBridge JDIRNALS}

